J. Ris. \& Ap. Mat. Vol. 5 No. 1 (2021) pp. 68-79

Jurnal Riset dan Aplikasi Matematika

e-ISSN: 2581-0154

URL: journal.unesa.ac.id/index.php/jram

\title{
OPTIMASI PENDISTRIBUSIAN PRODUK MENGGUNAKAN METODE INTEGER LINEAR PROGRAMMING (Studi Kasus: Pt Awet Sarana Sukses Gorontalo)
}

\author{
SAFRUDIN ISMAIL ${ }^{1 *}$, ISMAIL DJAKARIA ${ }^{2}$, DJIHAD WUNGGULI ${ }^{3}$ \\ 1,2,3Jurusan Matematika, Fakultas MIPA, Universitas Negeri Gorontalo \\ *wenoditoude@gmail.com
}

\begin{abstract}
ABSTRAK
Penelitian ini bertujuan untuk meminimumkan total biaya operasional pendistribusian produk pada PT. Awet Sarana Sukses Gorontalo menggunakan model optimasi Capacitated Vehicle Routing Problem with Time Windows (CVRPTW) dan diselesaikan menggunakan metode Integer Linear Programming (ILP). Manfaat dari penelitian ini untuk memberikan kontribusi penting pada perusahaan dalam melakukan perencanaan proses pendistribusian produk, dengan memperhatikan biaya operasional, rute terpendek yang dilalui dan waktu bongkar muat kendaraan (time windows). Dalam penelitian ini solusi yang didapatkan berupa solusi yang optimum yang dihasilkan dengan cara menjumlahkan nilai fungsi objektif dari ketiga wilayah yang dibuat. Hasil optimasi mendapatkan Nilai objektif sebesar Rp 675.660,- dengan menggunakan 6 kendaraan dari 33 kedaraan yang tersedia dan kendaraan melakukan proses pendistribusian sesuai dengan jenis produk yang dipesan serta tidak melebihi waktu time windows yang ditentukan oleh agen.
\end{abstract}

Kata Kunci: Capacitated Vehicle Routing Problem with Time Windows; Integer Linear Programming; PT. Awet Sarana Sukses Gorontalo

\section{ABSTRACT}

The research objective was to minimize the total operating cost of product distribution at PT. Awet Sarana Sukses Gorontalo by using Capacitated Vehicle Routing Problem with Time Windows (CVRPTW) optimization model and accomplished by using Integer Linear Programming (ILP). The research significance was to provide vital contribution at a company in doing product distribution process planning by paying attention to operating cost, the shortest route to pass, and dwelling time (time windows). In this research, the solution obtained is in the form of an optimum solution that is produced by adding the objective function values of the three regions created. The optimization results get an objective value of Rp. 675,660, - by using 6 of the 33 available vehicles and the vehicles carry out the distribution process according to the type of product ordered and do not exceed the time windows specified by the agent.

Keywords: Capacitated Vehicle Routing Problem with Time Windows; Integer Linear Programming; PT. Awet Sarana Sukses Gorontalo 


\section{Pendahuluan}

Salah satu metode riset operasi yang sering digunakan pada perusahaan dalam masalah manajemen atau perencanaan adalah metode Integer Linear Programming (ILP) [3]. ILP merupakan suatu metode yang memakai model matematis yang mengandung fungsi objektif, fungsi kendala dan variabel keputusan yang berupa bilangan bulat (integer) untuk menggambarkan masalah yang dihadapi. ILP memiliki tujuan dalam meminimumkan atau memaksimumkan sesuatu sesuai dengan kebutuhan yang diperlukan perusahaan. Penggunaan ILP lebih mudah karena dapat menambahkan atau menghilangkan kendala-kendala baru sesuai dengan kebutuhan. ILP dapat diselesaikan menggunakan bantuan software LINGO untuk masalah yang memiliki variabel banyak. Salah satu masalah yang dapat diselesaikan dengan metode ILP adalah masalah pendistribusian barang atau biasa disebut vehicle routing problem (VRP).

Model matematis VRP secara resmi diperkenalkan oleh Dantzig dan Ramser pada tahun 1959 sebagai masalah pendistribusian barang yang menggunakan truk. Dan sejak saat itu, variasi model VRP telah banyak yang muncul, antara lain: VRP yang memiliki kendaraan berkapasitas tersendiri untuk suatu barang yang akan dikirim disebut Capacitated Vehicle Routing Problem (CVRP) [5], VRP dengan adanya kendala selang waktu tertentu untuk melayani setiap agen disebut Vehicle Routing Problem with Time Windows (VRPTW) [2], dan sebagainya. Pada penelitian kali ini peneliti menggunakan model cavacitated vehicle routing problem with time windows (CVRPTW), yang merupakan gabungan dari dua jenis VRP, yaitu model CVRP dan VRPTW.

CVRPTW merupakan suatu jenis VRP yang memperhatikan kendala kapasitas kendaraan dan time windows (waktu bongkar muat) kendaraan. Faktor yang harus diperhatikan oleh perusahaan dalam melakukan proses distribusi produk tidak cukup hanya memenuhi jumlah permintaan saja, tapi juga ketepatan waktu pengiriman produk menjadi perhatian konsumen agar biaya pendistribusian dapat dikurangi dan tidak ada pemborosan dari segi waktu, jarak dan tenaga [1]. Salah satu masalah pendistribusian yang cocok dalam model matematis CVRPTW ini ialah masalah pendistribusian produk pada PT Awet Sarana Sukses (Wings) di Gorontalo.

Setelah masalah pendistribusian produk tersebut dimodelkan dalam bentuk model matematis CVRPTW, kemudian diselesaikan dengan menggunakan metode integer linear programming. Integer linear programming berperan penting dalam model tersebut untuk memilih jumlah kendaraan yang akan digunakan dengan menyesuaikan kapasitas muatan dan waktu bongkar muat kendaraan terhadap permintaan produk disetiap agen, sehingga akan mendapatkan biaya yang paling optimal untuk perusahaan tersebut.

\section{Tinjauan Pustaka}

\subsection{Linear Programming}

Menurut Winston [6], Definisi-definisi penting pada LP yaitu:

\section{Definisi 1}

Suatu fungsi $f\left(x_{1}, x_{2}, \ldots, x_{n}\right)$ dari $x_{1}, x_{2}, \ldots, x_{n}$ merupakan Fungsi Linear jika dan hanya jika untuk beberapa himpunan konstanta $c_{1}, c_{2}, \ldots, c_{n}, f\left(x_{1}, x_{2}, \ldots, x_{n}\right)=c_{1 x_{1}}+c_{2} x_{2}+\cdots+$ $c_{n} x_{n}$.

\section{Definisi 2}

Untuk setiap fungsi linear $f\left(x_{1}, x_{2}, \ldots, x_{n}\right)$, dan setiap bilangan $b$, pertidaksamaan $f\left(x_{1}, x_{2}, \ldots, x_{n}\right) \leq b$ dan $f\left(x_{1}, x_{2}, \ldots, x_{n}\right) \geq b$ merupakan Pertidaksamaan Linear. 


\section{Definisi 3}

Masalah linearProgramming (LP) merupakan masalah optimasi dengan ketentuan sebagai berikut:

1. Untuk memaksimumkan atau meminimumkan fungsi linear dari variabel keputusan. Fungsi yang akan dimaksimumkan atau diminimumkan disebut fungsi objektif.

2. Nilai dari variabel keputusan harus memenuhi semua fungsi kendala. Masing-masing fungsi kendala harus berupa persamaan linear atau pertidaksamaan linear

3. Fungsi pembatas berkaitan dengan masing-masing variabel. Untuk setiap variabel $x_{i}$, fungsi pembatas menetapkan bahwa $x_{i}$ harus bernilai non-negatif $\left(x_{i} \geq 0\right)$ atau tidak dibatasi dalam fungsi.

\subsection{Integer Linear Programming}

Menurut Winston [6], integer linear programming (ILP) merupakan suatu LP yang sebagian atau semua variabel yang digunakan merupakan bilangan bulat (integer) non-negatif. Ada tiga jenis ILP, yaitu :

1. Dimana semua variabel ILP harus bilangan bulat disebut Pure Integer Programming. Sebagai contoh,

$$
\begin{array}{ll}
\operatorname{Max} & z=3 x_{1}+2 x_{2} \\
\text { s.t } & x_{1}+x_{2} \leq 6 \\
& x_{1}, x_{2} \geq 0, x_{1}, x_{2} \quad \text { Integer }
\end{array}
$$

2. Dimana hanya beberapa variabel ILP yang diperlukan untuk menjadi bilangan bulat disebut Mixed Integer Programming. Sebagai contoh,

$$
\begin{array}{ll}
\text { Max } & z=3 x_{1}+2 x_{2} \\
\text { s.t } & x_{1}+x_{2} \leq 6 \\
& x_{1}, x_{2} \geq 0, x_{1} \quad \text { Integer }
\end{array}
$$

adalah Mixed integer programming ( $x_{2}$ tidak perlu menjadi bilangan bulat)

3. Dimana semua variabel ILP harus sama dengan 0 atau 1 disebut ILP 0-1. Sebagai contoh,

$$
\begin{array}{cl}
\operatorname{Max} & z=x_{1}-x_{2} \\
\text { s.t } & x_{1}+2 x_{2} \leq 2 \\
& 2 x_{1}-x_{2} \leq 1 \\
& x_{1}, x_{2}=0 \text { atau } 1
\end{array}
$$

\subsection{Traveling Salesman Problem}

Menurut Saji dan Riffi [7], Traveling Salesman Problem (TSP) diperkenalkan pada 1800-an oleh ahli matematika Irlandia W.R. Hamilton dan ahli matematika Inggris Thomas Kirkman, yang dinyatakan sebagai masalah permutasi dengan tujuan menemukan tur tertutup terpendek yang mengunjungi semua kota dalam himpunan tertentu. TSP dapat dimodelkan sebagai graph yang sepenuhnya terhubung dalam D-dimensi ruang Euclide (D merupakan Ukuran masalah), kota merupakan simpul atau node graph, jalur adalah edge graph, dan jarak jalur adalah panjang edge. Secara matematis, itu dapat didefinisikan sebagai satu himpunan kota $n\left(c_{1}, c_{2}, \ldots, c_{n}\right)$ dan permutasi $\pi_{1}, \cdots, \pi_{n}$ yang bertujuan untuk menemukan sejumlah permutasi $\pi_{i}=\left(c_{1}, c_{2}, \cdots, c_{n}\right)$ sedemikian sehingga meminimumkan $f(\pi)$ jumlah dari semua jarak Euclidean antara masing-masing kota dari jalur yang sama lebih jelasnya diberikan sebagai berikut: 


$$
f(\pi)=\sum_{i=1}^{n-1} d_{\pi(i) \pi(i+1)} d_{\pi(n) \pi(1)}
$$

Jarak Euclidean $d$, antara dua kota dengan koordinat $\left(x_{1}, y_{1}\right)$ dan $\left(x_{2}, y_{2}\right)$ dihitung oleh :

$$
d=\sqrt{\left(x_{1}, y_{1}\right)^{2}\left(x_{2}, y_{2}\right)^{2}}
$$

\subsection{Vehicle Routing Problem}

Dantzig dan Ramser (1959) adalah yang pertama kali memperkenalkan "Masalah Pengiriman Truk", memodelkan bagaimana armada truk homogen dapat melayani permintaan minyak dari sejumlah pompa bensin dari pusat hub dan dengan jarak tempuh minimum. Lima bertahun-tahun kemudian, Clarke dan Wright (1964) menggeneralisasi masalah ini ke masalah optimisasi linier yang biasa ditemui dalam domain logistik dan transportasi: yaitu, bagaimana melayani satu set pelanggan, secara geografis tersebar di sekitar depot pusat, menggunakan armada truk dengan berbagai kapasitas. Ini dikenal sebagai 'Vehicle Routing Problem' (VRP), salah satu topik yang paling banyak dipelajari di bidang Riset Operasi [4].

\subsection{Capacitated Vehicle Routing Problem}

Salah satu variasi VRP yang memperhatikan kendala kapasitas pada kendaraan untuk melayani sejumlah permintaan konsumen adalah Capacitated vehicle routing problem (CVRP). CVRP bertujuan untuk meminimumkan banyaknya kendaraan yang digunakan dan total waktu perjalanan. Solusi CVRP dikatakan fisibel jika jumlah total barang tidak melebihi kapasitas kendaraan yang melewati rute tersebut [5].

\subsection{Vehicle Routing Problem with Time Windows}

Menurut Kallehauge, vehicle routing problem with time windows (VRPTW) adalah masalah penentuan rute kendaraan dengan biaya minimum untuk melayani seluruh konsumen dan memenuhi kendala kapasitas kendaraan dan time windows pada setiap konsumen dan depot. Time windows pada depot didefinisikan sebagai selang waktu kendaraan berangkat dan kembali lagi ke depot. Time windows pada depot disebut juga scheduling horizon, yang berarti bahwa setiap kendaraan tidak boleh meninggalkan depot sebelum waktu awal depot dimulai dan harus kembali ke depot sebelum waktu akhir depot selesai [2].

\section{Metode}

\subsection{Metode Pengumpulan Data}

Metode pengumpulan data pada penelitian ini menggunakan data simulasi, data aproksimasi, dan data primer yang diperoleh secara langsung di PT Awet Sarana Sukses Gorontalo. Data primer tesebut merupakan data data nama-nama toko beserta lokasinya yang berada di Kabupaten Bone-Bolango dan Kota Gorontalo, Data jumlah kendaraan berserta kapasitasnya, dan jenis-jenis produk makanan yang didistribusikan. Data biaya operasional pendistribusian dengan data permintaan produk setiap pelanggan menggunakan data simulasi, karena data tersebut bersifat rahasia bagi perusahaan, Sedangkan data jarak antar-node menggunakan data aproksimasi yang diperoleh dari fitur Google Maps.

\subsection{Prosedur Analisis}

Adapun prosedur analisis yang digunakan dalam penelitian ini adalah sebagai berikut:

1. Identifikasi masalah dan kriteria pendistribusian produk.

2.Pembentukan model

3. Simulasi numerik 


\section{Interpretasi dan kesimpulan}

\section{Hasil dan Pembahasan}

\subsection{Deskripsi dan Asumsi Model}

Tempat penyimpanan produk dimisalkan sebagai depot dan keberadaan agen dimisalkan sebagi node. Kendaraan yang tersedia sejumlah $k$ dan memiliki kapasitas angkut tertentu. Time windows didefinisikan sebagai selang waktu kendaraan berangkat dan kembali lagi ke depot. Penentuan rute pendistribusian dapat dimodelkan dalam suatu ILP. Untuk membatasi permasalahan pada artikel ini digunakan asumsi-asumsi sebagai berikut:

1. Kendaran yang berangkat untuk melakukan proses distribusi dari depot harus kembali lagi ke depot awal.

2. Setiap agen hanya boleh dikunjungi tepat satu kali oleh satu kendaraan.

3. Banyaknya produk yang akan didistribusikan, tidak boleh melebihi kapasitas kendaraan yang digunakan.

4. Waktu pelayanan, permintaan pelanggan, biaya tetap dan biaya perjalanan menggunakan data simulasi.

5. Kecepatan semua jenis kendaraan konstan

6. Rute yang dilalui kendaraan tidak macet.

7. Proses distribusi tidak boleh melebihi time windows yang ditentukan

8. Biaya yang dipertimbangkan adalah jumlah dari biaya tetap dan biaya perjalan.

\subsection{Implementasi Model}

Dalam penelitian ini, peneliti mengambil studi kasus pendistribusian produk pada PT Awet Sarana Sukses Gorontalo. Perusahaan tersebut kemudian dimisalkan sebagai depot yang menjadi awal keberangkatan dan akhir proses distribusi. Time windows atau selang waktu kendaraan berangkat dan kembali lagi ke depot dari pukul 07.00-17.00 wita.

Depot memiliki 33 kendaraan dengan jenis dan kapasitas yang berbeda-beda, yaitu L300 memiliki kapasitas 1,5 ton sebanyak 7 buah, Engkel ban memiliki kapasitas 3 ton sebanyak 6 buah, Double ban memiliki kapasitas 6 ton sebanyak 18 buah, dan Fuso memiliki kapasitas 16 ton sebnyak 2 buah. Kecepatan semua jenis kendaraan dimisalkan konstan dan rute yang dilalui kendaraan tidak macet. Untuk data biaya operasional kendaraan, pihak perusahaan tidak memberikannya karena merupakan data yang bersifat rahasia bagi perusahaan. Sehingga itu peneliti hanya menggunakan data simulasi, yaitu untuk biaya Tetap semua jenis kendaraan adalah sebesar Rp 100.000,- sedangkan biaya per Km sebesar Rp 1.000,-.

Depot memiliki dua jenis produk, yaitu produk makanan dan produk rumah tangga (sabun). Karena produk makanan tidak bisa dimuat secara bersamaan dengan produk rumah tangga, maka Peneliti hanya akan fokus pada proses pendistribusian produk makanan. Untuk data permintaan produk, pihak perusahaan juga tidak memberikannya karena merupakan data yang bersifat rahasia bagi perusahaan. Begitu juga dengan Waktu pelayanan, waktu awal dan akhir pelayanan serta time windows setiap agen atau node menggunakan data simulasi.

Depot melayani hampir semua agen yang berada di provinsi gorontalo, akan tetapi peneliti hanya akan meneliti pada agen yang berada di kabupaten Bone-Bolango dan kota gorontalo sesuai dengan data yang diberikan oleh perusahaan. Kemudian peneliti membagi data tersebut menjadi tiga wilayah bagian, untuk lokasi yang berada di kota gorontalo menjadi dua wilayah, sedangkan Bone Bolango menjadi satu wilayah. Wilayah-wilayah tersebut memuat beberapa toko atau agen yang akan dimisalkan sebagai node. Penentuan jarak setiap lokasi menggunakan data aproksimasi yang diperoleh dari fitur Google Maps. 
Wilayah A Pada wilayah A terdapat agen-agen yang berada di kecamatan kota utara, kota selatan dan kota tengah. Kemudian akan dimodelkan kedalam model CVRPTW, dan diselesaikan menggunakan metode integer linear programming untuk mendapatkan rute yang optimal, biaya optimal, jumlah kendaraan yang digunakan dan waktu bongkar muat untuk setiap kendaraan yang terpilih.

\section{Himpunan}

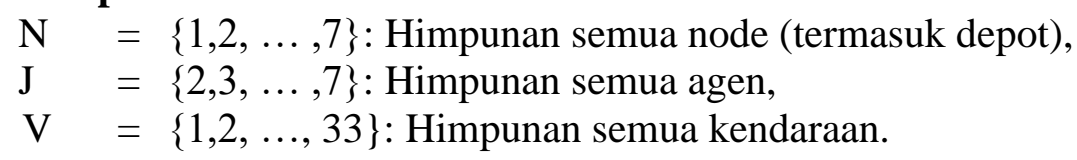

\section{Indeks}

$\mathrm{i}, \mathrm{j}, \mathrm{p}=\{1,2, \ldots, 7\}:$ Indeks untuk menyatakan node,

$\mathrm{k}=\{1,2, \ldots, 33\}:$ Indeks untuk menyatakan kendaraan

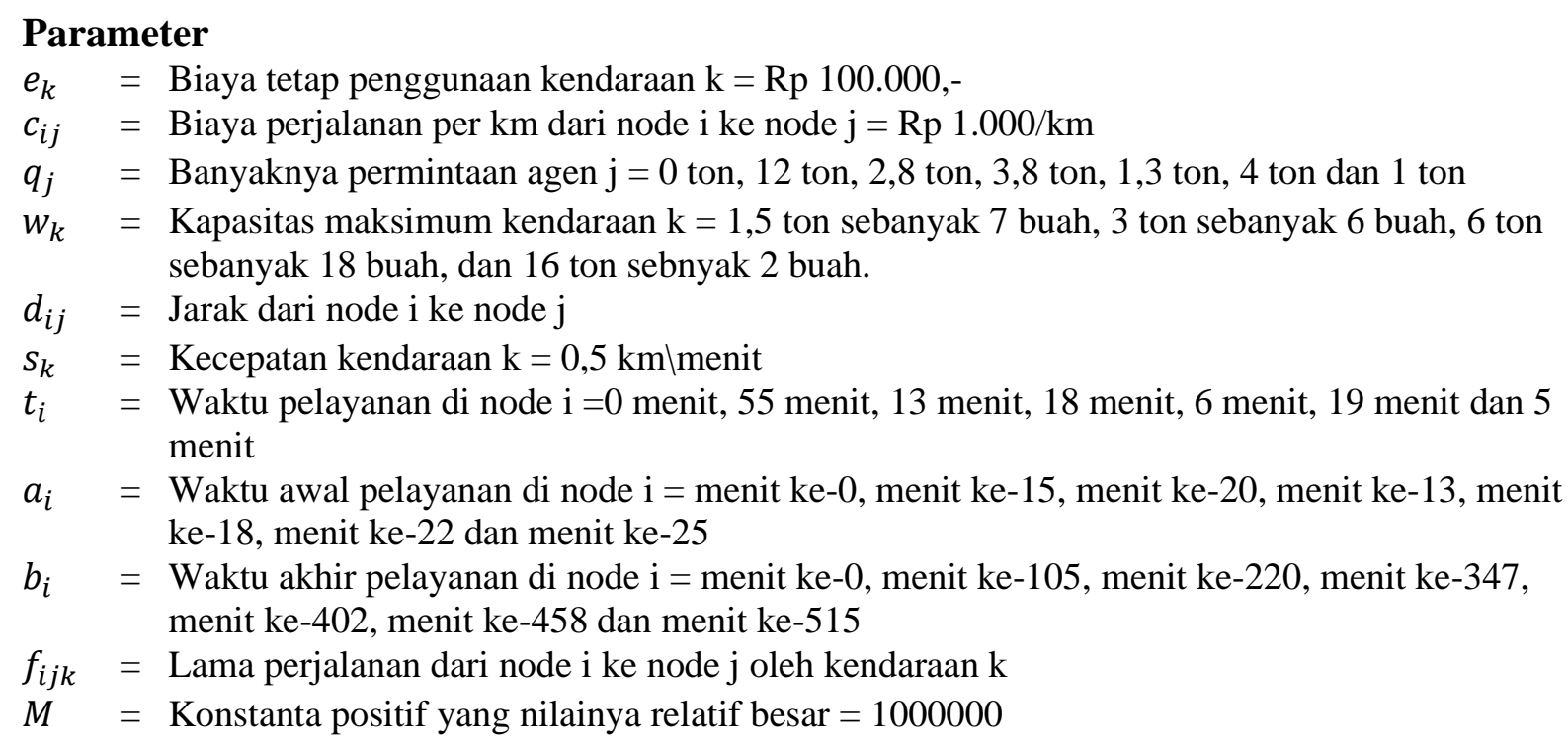

Variabel Keputusan Model

$X_{i j k}=\left\{\begin{array}{c}1, \text { jika node } j \text { dikunjungi setelah node } i \text { oleh kendaraan } k \\ 0, \text { lainnya }\end{array}\right.$

$Y_{k}=\left\{\begin{array}{c}1, \text { jika kendaraan } k \text { digunakan untuk melakukan proses distribusi } \\ \text { 0, lainnya }\end{array}\right.$

$Z_{i k}=$ Waktu pelayanan di node $i$ oleh kendaraan $k$,

$U_{i k}=$ Variabel tambahan yang digunakan dalam eliminasi subtour untuk agen $i$ pada kendaraan $k$,

$U_{j k}=$ Variabel tambahan yang digunakan dalam eliminasi subtour untuk agen $j$ pada kendaraan $k$,

\section{Fungsi Tujuan}

Fungsi tujuan model yaitu untuk meminimumkan biaya operasional pendistribusian produk, yang ditinjau dari penjumlahan biaya tetap penggunaan kendaraan ditambah dengan biaya perjalanan.

$$
\operatorname{Min} z=\sum_{k=1}^{33}\left(e_{k} \times Y_{k}\right)+\sum_{i=1}^{7} \sum_{j=1}^{7} \sum_{k=1}^{33}\left(c_{i j} \times X_{i j k}\right)
$$




\section{Fungsi Kendala}

Kendala yang harus dipenuhi adalah sebagai berikut:

1. Setiap kendaraan akan berangkat dari depot dan tidak harus semua kendaraan digunakan.

$$
\sum_{j=2}^{7} X_{1 j k}, \quad \forall k=\{1,2, \ldots, 33\}
$$

2. Kendaraan yang digunakan harus kembali ke depot yang sama saat ia berangkat.

$$
\sum_{j=2}^{7} X_{j 1 k}=Y_{k}, \quad \forall k=\{1,2, \ldots, 33\}
$$

3. Setiap agen dilayani tepat sekali oleh sebuah kendaraan.

$$
\begin{array}{ll}
\sum_{i=1}^{7} \sum_{k=1}^{33} X_{i j k}, & \forall j=\{2,3, \ldots, 7\} \\
\sum_{j=1}^{7} \sum_{k=1}^{33} X_{i j k}, & \forall i=\{2,3, \ldots, 7\}
\end{array}
$$

4. Rute harus kontinu, artinya setiap kendaraan yang mengunjungi suatu agen pasti akan meninggalkan agen tersebut.

$$
\sum_{i=1, i \neq p}^{7} X_{i p k}-\sum_{j=1, j \neq p}^{7} X_{p j k}=0, \quad \forall p \neq j, \quad \forall k=\{1,2, \ldots, 33\}
$$

5. Total permintaan dari semua agen yang dilalui oleh setiap kendaraan tidak boleh melebihi kapasitas maksimum kendaraan yang digunakan.

$$
\sum_{i=2}^{7} \sum_{j=2}^{7} q_{i} \times X_{i j k} \leq w_{k}, \quad \forall i \neq j, \quad \forall k=\{1,2, \ldots, 33\}
$$

6. Tidak ada agen yang dikunjungi oleh kendaraan yang tidak digunakan.

$$
X_{i j k} \leq Y_{k}, \quad \forall i, j=\{1,2, \ldots, 7\}, \quad \forall k=\{1,2, \ldots, 33\}
$$

7. Tidak ada perjalanan ke tempat yang sama.

$$
X_{i i k}=0, \quad \forall i=\{1,2, \ldots, 7\}, \quad \forall k=\{1,2, \ldots, 33\}
$$

8. Lama perjalanan dipengaruhi oleh jarak antara konsumen dan kecepatan kendaraan.

$$
f_{i j k}=\frac{d_{i j}}{s_{k}}, \quad \forall i \neq j, \quad \forall i, j=\{1,2, \ldots, 7\}, \quad \forall k=\{1,2, \ldots, 33\}
$$

9. Jumlah dari waktu pelayanan di node $i$ dengan waktu perjalanan dari node $i$ ke node $j$ harus kurang dari atau sama dengan waktu pelayanan di node $j$,

$$
Z_{i k}+t_{i}+f_{i j}-M_{i j}\left(1-X_{i j k}\right) \leq Z_{j k}, \quad \forall j=\{2,3, \ldots, 7\}, \quad \forall k=\{1,2, \ldots, 33\}
$$

dengan $M_{i j}$ adalah konstanta besar yang tidak kurang dari nilai maksimum dari $b_{i}+f_{i j}-$ $a_{i} ; i, j=\{1,2, \ldots, 7\}$

10. Waktu pelayanan disetiap konsumen memenuhi time windows.

$$
\begin{array}{cc}
a_{i} \leq Z_{i k}, \quad \forall i=\{1,2, \ldots, 7\}, & \forall k=\{1,2, \ldots, 33\} \\
Z_{i k}+t_{i} \leq b_{i}, \quad \forall i=\{1,2, \ldots, 7\}, \quad \forall k=\{1,2, \ldots, 33\}
\end{array}
$$

11. Kendala eliminasi subtour yang bertujuan membentuk adanya tour yang fisibel.

$$
U_{i k}-U_{j k}+N X_{i j k} \leq N-1, \quad \forall i, j=\{2,3, \ldots, 7\}, \quad \forall k=\{1,2, \ldots, 33\}
$$

12. Kendala biner dan ketaknegatifan.

$$
\begin{gathered}
X_{i j k} \in\{0,1\}, \quad \forall i, j \in N, \quad i \neq j, \quad \forall k=\{1,2, \ldots, 33\} \\
Y_{k} \in\{0,1\}, \quad \forall k=\{1,2, \ldots, 33\} \\
Z_{i k} \geq 0, \quad \forall i=\{2,3, \ldots, 7\}, \quad \forall k=\{1,2, \ldots, 33\} \\
U_{i k} \geq 0, \quad \forall i=\{2,3, \ldots, 7\}, \quad \forall k=\{1,2, \ldots, 33\}
\end{gathered}
$$




$$
U_{j k} \geq 0, \quad \forall j \in\{2,3, \ldots, 7\}, \quad \forall k=\{1,2, \ldots, 33\}
$$

Wilayah B Pada wilayah B terdapat agen-agen yang berada di kecamatan kota utara, kota timur dan kota barat. Kemudian akan dimodelkan kedalam model CVRPTW dan diselesaikan menggunakan metode integer linear programming seperti pada wilayah A. Nilai dari setiap parameter menggunakan data yang ada pada wilayah B dan untuk kendaraan yang telah digunakan pada wilayah A tidak dapat digunakan pada wilayah B.

Wilayah C Pada wilayah C terdapat agen-agen yang berada di kabupaten Bone Bolango. Kemudian akan dimodelkan kedalam model CVRPTW dan diselesaikan menggunakan metode integer linear programming seperti pada wilayah A dan B. Nilai dari setiap parameter menggunakan data yang ada pada wilayah $\mathrm{C}$ dan untuk kendaraan yang telah digunakan pada wilayah A dan B tidak dapat digunakan pada wilayah C.

\subsection{Hasil Optimasi}

Telah dijelaskan pada sub bab sebelumnya bahwa tujuan dari penelitian ini adalah membuat model optimasi pendistribusian produk untuk meminimumkan biaya operasional yang ditinjau dari penjumlahan biaya tetap penggunaan kendaraan ditambah dengan biaya perjalanan. Selanjutnya model pendistribusian ini dibuat dengan memperhatikan syarat-syarat ataupun kendala-kendala yang ada pada pendistribusian produk. Syarat dan kendala tersebut telah diformulasikan kedalam 12 fungsi kendala yang telah dibuat beserta dengan nilai parameternya. Model pendistribusian produk ini diselesaikan dengan menggunakan metode integer linear programming dengan bantuan software LINGO 11.0. Dari hasil perhitungan pada model wilayah A diperoleh solusi optimal dengan nilai fungsi objektif sebesar Rp.224.250,- dengan waktu running 14 detik.

\begin{tabular}{|c|c|c|}
\hline \multicolumn{2}{|c|}{ Global optimal solution found } & 224250.0 \\
\hline \multicolumn{2}{|c|}{ objective bound: } & 224250.0 \\
\hline \multicolumn{2}{|c|}{ Infeasibilities: } & 0.000000 \\
\hline \multicolumn{2}{|c|}{ Extended solver steps: } & 186 \\
\hline \multicolumn{2}{|c|}{ Total solver iterations: } & 10340 \\
\hline Variable & Value & Reduced Cost \\
\hline$x(1,2,33)$ & 1.000000 & 4700.000 \\
\hline$x(1,3,32)$ & 1.000000 & 4000.000 \\
\hline$x(2,1,33)$ & 1.000000 & 4700.000 \\
\hline$x(3,4,32)$ & 1.000000 & 500.0000 \\
\hline$x(4,7,32)$ & 1.000000 & 3400.000 \\
\hline$x(5,6,32)$ & 1.000000 & 1300.000 \\
\hline$x(6,1,32)$ & 1.000000 & 4900.000 \\
\hline$x(7,5,32)$ & 1.000000 & 750.0000 \\
\hline
\end{tabular}

Gambar 1. Hasil output software LINGO 
Berdasarkan Gambar 1. dapat dilihat bahwa solusi integer dari permasalahan pada wilayah A adalah $\mathrm{X}(1,2,33), \mathrm{X}(2,1,33)=1$ dan $\mathrm{X}(1,3,32), \mathrm{X}(3,4,32), \mathrm{X}(4,7,32), \mathrm{X}(7,5,32)$, $\mathrm{X}(5,6,32), \mathrm{X}(6,1,32)=1$, sehingga menghasilkan nilai objektif yang optimum sebesar $\mathrm{Rp}$ 224.250,- dengan menggunakan 2 kendaraan yang berkapasitas 16 ton dari 33 kendaraan yang tersedia, yaitu kendaraan 32 dan 33, dan untuk kedua kendaraan tersebut tiba di depot setelah mendistribusikan semua produk pada wilayah A sebelum pukul 17.00, sehingga tidak melewati waktu bongkar muat kendaraan yang telah ditentukan. Lebih jelasnya dapat dilihat pada Tabel 1 dan 2.

Sedangkan pada wilayah B solusi integernya adalah $\mathrm{X}(1,2,30), \mathrm{X}(2,3,30), \mathrm{X}(3,1,30)=$ 1 dan $X(1,6,31), X(6,5,31), X(5,4,31), X(4,1,31)=1$, sehingga menghasilkan nilai objektif yang optimum sebesar Rp 221.010,- dengan menggunakan 2 kendaraan yang berkapasitas 6 ton dari 30 kendaraan yang tersedia, yaitu kendaraan 30 dan 31, dan untuk kedua kendaraan tersebut tiba di depot setelah mendistribusikan semua produk pada wilayah B sebelum pukul 17.00, sehingga tidak melewati waktu bongkar muat kendaraan yang telah digunakan. Lebih jelasnya dapat dilihat pada Tabel 1 dan 2.

Dan untuk wilayah C solusi integernya adalah $\mathrm{X}(1,2,25), \mathrm{X}(2,6,25), \mathrm{X}(6,3,25), \mathrm{X}(3,1,25)$ $=1$ dan $X(1,4,17), X(4,5,17), X(5,1,17)=1$, sehingga menghasilkan nilai objektif yang optimum sebesar Rp 230.400,- dengan menggunakan 2 kendaraan yang berkapasitas 6 ton dari 28 kendaraan yang tersedia, yaitu kendaraan 17 dan 25, dan untuk kedua kendaraan tersebut tiba di depot setelah mendistribusikan semua produk pada wilayah $\mathrm{C}$ sebelum pukul 17.00, sehingga tidak melewati waktu bongkar muat kendaraan yang telah digunakan. Lebih jelasnya dapat dilihat pada Tabel 1 dan 2.

Untuk mengetahui nilai fungsi objektif atau total biaya yang dikeluarkan oleh perusahaan ialah dengan cara menjumlahkan nilai fungsi objektif dari ketiga wilayah tersebut, yaitu sebesar Rp 675.660,- dengan hanya menggunakan 6 kendaraan dari 33 kendaraan yang tersedia. Hasil optimasi lebih jelas dapat di lihat pada Tabel 1 .

Tabel 1. Hasil penentuan rute optimal Model 1

\begin{tabular}{|c|c|c|c|c|}
\hline Nomor & Akumulasi & $\begin{array}{c}\text { Akumulasi } \\
\text { muatan } \\
\text { Kendaraan }\end{array}$ & $\begin{array}{c}\text { Biaya } \\
\text { jarak }(\mathrm{km})\end{array}$ & Rute Yang terbentuk \\
\hline 1 & - & - & - & - \\
\hline 2 & - & - & - & - \\
\hline 3 & - & - & - & - \\
\hline 4 & - & - & - & - \\
\hline 5 & - & - & - & - \\
\hline 6 & - & - & - & - \\
\hline 7 & - & - & - & - \\
\hline 8 & - & - & - & - \\
\hline 9 & - & - & - & - \\
\hline 10 & - & - & - & - \\
\hline 11 & - & - & - & - \\
\hline 12 & - & - & - & - \\
\hline 13 & - & - & - & - \\
\hline 14 & - & - & - & - \\
\hline 15 & - & - & - & - \\
\hline 16 & - & - & - & \\
\hline
\end{tabular}




\begin{tabular}{|c|c|c|c|c|}
\hline $\begin{array}{l}\text { Nomor } \\
\text { Kendaraan }\end{array}$ & $\begin{array}{l}\text { Akumulasi } \\
\text { jarak }(\mathrm{km})\end{array}$ & $\begin{array}{l}\text { Akumulasi } \\
\text { muatan } \\
\text { (ton) }\end{array}$ & $\begin{array}{l}\text { Biaya } \\
(\mathrm{Rp})\end{array}$ & Rute Yang terbentuk \\
\hline 17 & 15,5 & 3,2 & 115.500 & $\begin{array}{l}1 \rightarrow \mathrm{C} 4[\mathrm{a}(1), \mathrm{b}(1), \mathrm{c}(1)] \rightarrow \mathrm{C} 5[\mathrm{~b}(1), \mathrm{t}(1), \\
\mathrm{u}(0,2)] \rightarrow 1\end{array}$ \\
\hline 18 & - & - & - & - \\
\hline 19 & - & - & - & - \\
\hline 20 & - & - & - & - \\
\hline 21 & - & - & - & - \\
\hline 22 & - & - & - & - \\
\hline 23 & - & - & - & - \\
\hline 24 & - & - & - & - \\
\hline 25 & 14,9 & 5,7 & 114.900 & $\begin{array}{l}1 \rightarrow \mathrm{C} 2[\mathrm{~b}(1), \mathrm{f}(1), \mathrm{n}(0,5)] \rightarrow \mathrm{C} 6[\mathrm{k}(1), 1(0,3)] \\
\rightarrow \mathrm{C} 3[1(1), \mathrm{m}(0,3)] \rightarrow 1\end{array}$ \\
\hline 26 & - & - & - & - \\
\hline 27 & - & - & - & - \\
\hline 28 & - & - & - & - \\
\hline 29 & - & - & - & - \\
\hline 30 & 4,36 & 4 & 104.360 & $\begin{array}{l}1 \rightarrow \mathrm{B} 2[\mathrm{r}(1), \mathrm{s}(0,8)] \rightarrow \mathrm{B} 3[\mathrm{e}(1), \mathrm{i}(1), \mathrm{m}(0,2)] \\
\rightarrow 1\end{array}$ \\
\hline 31 & 16,65 & 4,9 & 116.650 & $\begin{array}{l}1 \rightarrow \mathrm{B} 6[\mathrm{f}(1), \mathrm{u}(0,7)] \rightarrow \mathrm{B} 5[\mathrm{~d}(1), \mathrm{j}(1)] \rightarrow \mathrm{B} 4 \\
{[\mathrm{a}(0,2), \mathrm{f}(1)] \rightarrow 1}\end{array}$ \\
\hline 32 & 14,85 & 12,9 & 114.850 & $\begin{array}{l}1 \rightarrow \mathrm{A} 3[\mathrm{~d}(1), \mathrm{h}(1), \mathrm{o}(0,8)] \rightarrow \mathrm{A} 4[\mathrm{f}(1), \mathrm{g}(1), \mathrm{j}(1), \\
\mathrm{r}(0,8)] \rightarrow \mathrm{A} 7[\mathrm{~h}(0,5), \mathrm{u}(0,5)] \rightarrow \mathrm{A} 6[\mathrm{~b}(1), \mathrm{f}(1), \\
\mathrm{i}(1), 1(1)] \rightarrow 1\end{array}$ \\
\hline 33 & 9,4 & 12 & 109.400 & $1 \rightarrow \mathrm{A} 2[\mathrm{a}(1), \mathrm{g}(3), \mathrm{i}(1), \mathrm{k}(3), \mathrm{m}(2), \mathrm{p}(2)] \rightarrow 1$ \\
\hline Total & 75,66 & 42,7 & 675.660 & \\
\hline
\end{tabular}

Huruf dalam [] menunjukkan jenis produk yang didistribusikan dan () menunjukkan banyaknya produk yang didistribusikan dalam ton untuk setiap node.

Total waktu keseluruhan untuk setiap kendaraan pada implementasi model menghasilkan waktu yang kurang dari time windows yang ditentukan, hasil optimasi untuk waktu setiap kendaraan dapat dilihat pada Tabel 2.

Tabel 2. Hasil penentuan rute optimal

\begin{tabular}{|c|c|c|c|c|c|c|}
\hline Kendaraan & Rute & $\begin{array}{c}\text { Lama } \\
\text { perjalanan } \\
\text { (fijk) }\end{array}$ & $\begin{array}{c}\text { Waktu } \\
\text { mulai } \\
\text { dilayani } \\
\text { (zik) }\end{array}$ & $\begin{array}{c}\text { Lama } \\
\text { Pelayanan } \\
\text { (tik) }\end{array}$ & $\begin{array}{c}\text { waktu } \\
\text { toleransi }\end{array}$ & $\begin{array}{c}\text { time } \\
\text { windows } \\
\text { [ai,bi] }\end{array}$ \\
\hline 1 & - & - & - & - & - & - \\
\hline 2 & - & - & - & - & - & - \\
\hline 3 & - & - & - & - & - & - \\
\hline 4 & - & - & - & - & - & - \\
\hline 5 & - & - & - & - & - & - \\
\hline 6 & - & - & - & - & - & - \\
\hline
\end{tabular}




\begin{tabular}{|c|c|c|c|c|c|c|}
\hline Kendaraan & Rute & $\begin{array}{c}\text { Lama } \\
\text { perjalanan } \\
(\text { fijk) }\end{array}$ & $\begin{array}{c}\text { Waktu } \\
\text { mulai } \\
\text { dilayani } \\
\text { (zik) }\end{array}$ & $\begin{array}{c}\text { Lama } \\
\text { Pelayanan } \\
\text { (tik) }\end{array}$ & $\begin{array}{l}\text { waktu } \\
\text { toleransi }\end{array}$ & $\begin{array}{c}\text { time } \\
\text { windows } \\
\text { [ai,bi] }\end{array}$ \\
\hline 7 & - & - & - & - & - & - \\
\hline 8 & - & - & - & - & - & - \\
\hline 9 & - & - & - & - & - & - \\
\hline 10 & - & - & - & - & - & - \\
\hline 11 & - & - & - & - & - & - \\
\hline 12 & - & - & - & - & - & - \\
\hline 13 & - & - & - & - & - & - \\
\hline 14 & - & - & - & - & - & - \\
\hline 15 & - & - & - & - & - & - \\
\hline 16 & - & - & - & - & - & - \\
\hline \multirow{3}{*}{17} & $1 \rightarrow \mathrm{C} 4$ & 12,2 & 12,2 & 14 & 0 & $07.12-13.00$ \\
\hline & $\mathrm{C} 4 \rightarrow \mathrm{C} 5$ & 4,4 & 30,6 & 10 & 26,2 & $07.10-15.00$ \\
\hline & $\mathrm{C} 5 \rightarrow 1$ & 14,4 & - & - & - & $07.00-17.00$ \\
\hline 18 & - & - & - & - & - & - \\
\hline 19 & - & - & - & - & - & - \\
\hline 20 & - & - & - & - & - & - \\
\hline 21 & - & - & - & - & - & - \\
\hline 22 & - & - & - & - & - & - \\
\hline 23 & - & - & - & - & - & - \\
\hline 24 & - & - & - & - & - & - \\
\hline \multirow{4}{*}{25} & $1 \rightarrow \mathrm{C} 2$ & 1,8 & 20 & 12 & 18,2 & $07.20-10.00$ \\
\hline & $\mathrm{C} 2 \rightarrow \mathrm{C} 6$ & 12,4 & 44,4 & 6 & 32 & $07.09-16.00$ \\
\hline & $\mathrm{C} 6 \rightarrow \mathrm{C} 3$ & 7 & 57,4 & 6 & 50,4 & $07.17-12.00$ \\
\hline & $\mathrm{C} 3 \rightarrow 1$ & 8,6 & - & - & - & $07.00-17.00$ \\
\hline 26 & - & - & - & - & - & - \\
\hline 27 & - & - & - & - & - & - \\
\hline 28 & - & - & - & - & - & - \\
\hline 29 & - & - & - & - & - & - \\
\hline \multirow{3}{*}{30} & $1 \rightarrow \mathrm{B} 2$ & 0,32 & 25 & 9 & 26,48 & $07.25-09.00$ \\
\hline & $\mathrm{B} 2 \rightarrow \mathrm{B} 3$ & 4 & 104,8 & 10 & 100,8 & $07.13-11.00$ \\
\hline & $\mathrm{B} 3 \rightarrow 1$ & 4,4 & - & - & - & $07.00-17.00$ \\
\hline \multirow{4}{*}{31} & $1 \rightarrow \mathrm{B} 6$ & 16,4 & 16,4 & 8 & 0 & $07.05-16.00$ \\
\hline & $\mathrm{B} 6 \rightarrow \mathrm{B} 5$ & 1,7 & 26,1 & 10 & 24,4 & $07.10-15.00$ \\
\hline & $\mathrm{B} 5 \rightarrow \mathrm{B} 4$ & 10,8 & 46,9 & 6 & 36,1 & $07.12-14.00$ \\
\hline & $\mathrm{B} 4 \rightarrow 1$ & 4,4 & - & - & - & $07.00-17.00$ \\
\hline \multirow{5}{*}{32} & $1 \rightarrow \mathrm{A} 3$ & 8 & 20 & 13 & 12 & $07.20-11.00$ \\
\hline & $\mathrm{A} 3 \rightarrow \mathrm{A} 4$ & 1 & 34 & 18 & 33 & $07.13-13.00$ \\
\hline & $\mathrm{A} 4 \rightarrow \mathrm{A} 7$ & 6,8 & 58,8 & 5 & 52 & $07.25-16.00$ \\
\hline & $\mathrm{A} 7 \rightarrow \mathrm{A} 5$ & 1,5 & 65,3 & 6 & 63,8 & $07.18-14.00$ \\
\hline & $\mathrm{A} 5 \rightarrow \mathrm{A} 6$ & 2,6 & 313,6 & 19 & 311 & $07.22-15.00$ \\
\hline
\end{tabular}




\begin{tabular}{|c|c|c|c|c|c|c|}
\hline Kendaraan & Rute & $\begin{array}{c}\text { Lama } \\
\text { perjalanan } \\
\text { (fijk) }\end{array}$ & $\begin{array}{c}\text { Waktu } \\
\text { mulai } \\
\text { dilayani } \\
\text { (zik) }\end{array}$ & $\begin{array}{c}\text { Lama } \\
\text { Pelayanan } \\
\text { (tik) }\end{array}$ & $\begin{array}{c}\text { waktu } \\
\text { toleransi }\end{array}$ & $\begin{array}{c}\text { time } \\
\text { windows } \\
\text { [ai,bi] }\end{array}$ \\
\hline \multirow{2}{*}{33} & A6 $\rightarrow 1$ & 9,8 & - & - & - & $07.00-17.00$ \\
\cline { 2 - 7 } & $1 \rightarrow \mathrm{A} 2$ & 9,4 & 15 & 55 & 5,6 & $07.15-09.00$ \\
\hline
\end{tabular}

\section{Kesimpulan}

Permasalahan penentuan rute pendistribusian produk pada PT Wings Sarana Sukses Gorontalo dapat dimodelkan sebagai capacitated vehicle routing problem with time windows (CVRPTW) dan dapat diselesaikan menggunakan metode integer linear programming. Solusi integer dari permasalahan pada wilayah $\mathrm{A}$ adalah $\mathrm{X}(1,2,33), \mathrm{X}(2,1,33)=1$ dan $\mathrm{X}(1,3,32)$, $\mathrm{X}(3,4,32), \mathrm{X}(4,7,32), \mathrm{X}(7,5,32), \mathrm{X}(5,6,32), \mathrm{X}(6,1,32)=1$, sehingga menghasilkan nilai objektif yang optimum sebesar Rp 224.250,-, Sedangkan pada wilayah B solusi integernya adalah $\mathrm{X}(1,2,30), \mathrm{X}(2,3,30), \mathrm{X}(3,1,30)=1$ dan $\mathrm{X}(1,6,31), \mathrm{X}(6,5,31), \mathrm{X}(5,4,31), \mathrm{X}(4,1$, $31)=1$, sehingga menghasilkan nilai objektif yang optimum sebesar Rp 221.010,-, Dan untuk wilayah $C$ solusi integernya adalah $X(1,2,25), X(2,6,25), X(6,3,25), X(3,1,25)=1$ dan $\mathrm{X}(1,4,17), \mathrm{X}(4,5,17), \mathrm{X}(5,1,17)=1$, sehingga menghasilkan nilai objektif yang optimum sebesar Rp 230.400,-

Untuk mengetahui nilai fungsi objektif atau total biaya yang dikeluarkan oleh perusahaan ialah dengan cara menjumlahkan nilai fungsi objektif dari ketiga wilayah tersebut, yaitu sebesar Rp 675.660,- dengan hanya menggunakan 6 kendaraan dari 33 kendaraan yang tersedia, yaitu kendaraan 17, 25, 30, 31, 32 dan 33 serta kendaraan tersebut melakukan proses pendistribusian sesuai dengan jenis produk yang dipesan serta tidak melebihi waktu time windows yang ditentukan oleh agen. Implementasi kedua model diselesaikan menggunakan software LINGO 11.0 pada komputer berspesifikasi CPU 2.41 GHZ dan RAM 2 GB

\section{Daftar Pustaka}

[1] E. Adriantantri, J. D. Irawan, and S. Indriani, "Implementasi Metode Saving Matriks Pada Program Komputer Untuk Penentuan Pendistribusian Produk," Ind. Inov. J. Tek. Ind., vol. 5, no. 1, pp. 10-14, 2015.

[2] D. Lalang, B. Silalahi, and F. Bukhari, "Vehicle Routing Problem Time Windows Dengan Pengemudi Sesekali," J. Math. Its Appl., vol. 17, no. 2, p. 87, 2018.

[3] G. Klosowski, E. Kozlowski, and A. Gola, "Integer Linear Programming in Optimization of Waste After Cutting in the Furniture Manufacturing," vol. 17, pp. 4352, 2016.

[4] K. Braekers, K. Ramaekers, and I. Van Nieuwenhuyse, "The vehicle routing problem: State of the art classification and review," Comput. Ind. Eng., vol. 99, pp. 300-313, 2016.

[5] V. Wahyuni, "Penyelesaian Capacitated Vehicle Routing Problem Menggunakan Greedy Randomized Adaptive Search Procedure," Institut Pertanian Bogor, 2015.

[6] W. L. Wiston, Operation Research: Application and Algorithm, Fourth Edi. Canada: Thomson, 2000.

[7] Y. Saji and M. E. Riffi, "A novel discrete bat algorithm for solving the travelling salesman problem," Neural Comput. Appl., vol. 27, no. 7, pp. 1853-1866, 2016. 